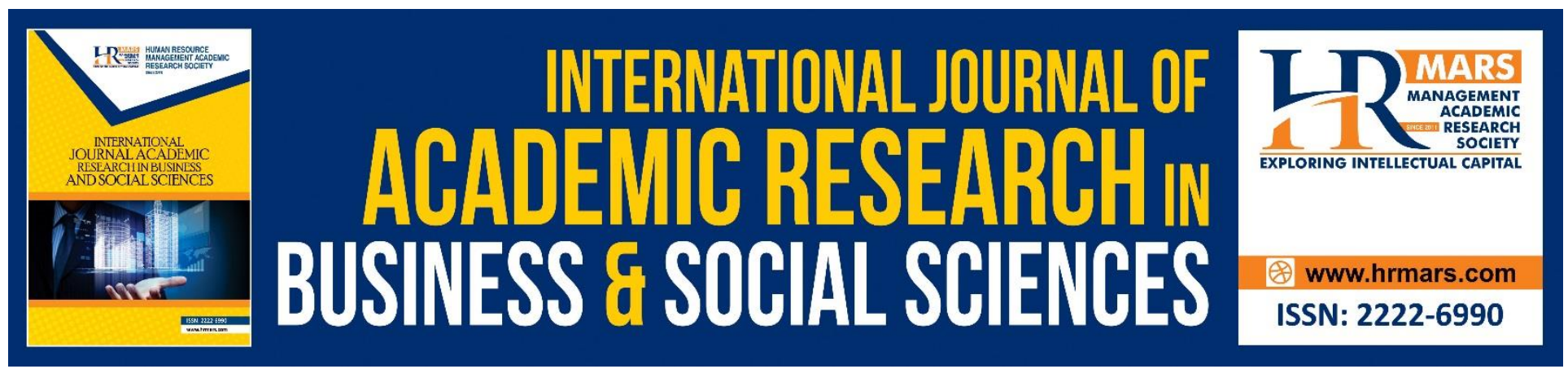

\title{
Curriculum Management Competency of Malaysia's Principals
}

Bity Salwana Alias, Zaida Nor Zainudin and Nurfaradilla Mohamad Nasri

To Link this Article: http://dx.doi.org/10.6007/IJARBSS/v8-i10/4830

DOI: $10.6007 /$ IJARBSS/v8-i10/4830

Received: 11 Sept 2018, Revised: 17 Oct 2018, Accepted: 29 Oct 2018

Published Online: 14 Nov 2018

In-Text Citation: (Alias, Zainudin, \& Nasri, 2018)

To Cite this Article: Alias, B. S., Zainudin, Z. N., \& Nasri, N. M. (2018). Curriculum Management Competency of Malaysia's Principals. International Journal of Academic Research in Business and Social Sciences, 8(10), 1101-1107.

Copyright: (C) 2018 The Author(s)

Published by Human Resource Management Academic Research Society (www.hrmars.com)

This article is published under the Creative Commons Attribution (CC BY 4.0) license. Anyone may reproduce, distribute, translate and create derivative works of this article (for both commercial and non-commercial purposes), subject to full attribution to the original publication and authors. The full terms of this license may be seen

at: http://creativecommons.org/licences/by/4.0/legalcode

Vol. 8, No. 10, 2018, Pg. 1101 - 1107

http://hrmars.com/index.php/pages/detail/IJARBSS

JOURNAL HOMEPAGE

Full Terms \& Conditions of access and use can be found at http://hrmars.com/index.php/pages/detail/publication-ethics 


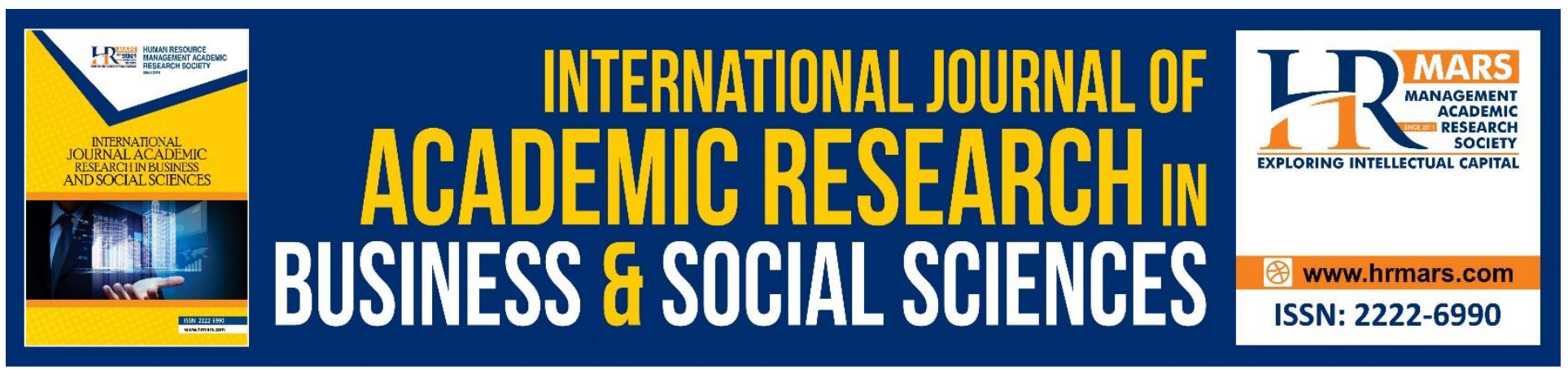

\title{
Curriculum Management Competency of Malaysia's Principals
}

\section{Bity Salwana Alias, Zaida Nor Zainudin and Nurfaradilla Mohamad Nasri}

Faculty of Education, Universiti Kebangsaan Malaysia, Bangi, Selangor, Malaysia

Faculty of Educational Studies, Universiti Putra Malaysia, 43400 UPM Serdang, Selangor, Malaysia

\begin{abstract}
Previous studies show that there are still issues of Malaysia principal competency in managing curriculum. Therefore the purpose of this study is to identify how far this statement is true and to recommend the best solution in handling this issue. The definition of competency in this study is the level of knowledge and skill that principals have in managing curriculum. To get the data, questionnaires has been sent to 314 principals, 720 senior assistants, and 611 senior teachers from all over Malaysia. Findings show that based on principals self evaluation and their subordinates evaluation, overall, principals competency in managing curriculum is at a high level with a mean score 4.30. Principals self evaluation also show that their knowledge to plan strategies to improve curriculum achievement is at a very high level but their skills to ensure teachers give priority to teaching and learning, to ensure curriculum change that is fully implemented, to encourage cooperation among teachers in implementing teaching and learning, and to mobilize effective programs are still at a medium level. Based on these findings, this study recommends that all principals must attend leadership training before being appointed as principals.
\end{abstract}

Keywords: Principal, Knowledge, Skills, Managing, Curriculum

\section{Introduction}

School is the educational organization with principals acting as managers. The principals bear the trust to manage efficiently and effectively to ensure that school goals are met (Abd. Razak \& Abdullah, 2003). The findings of previous studies show that effective management and leadership are the key factors that determine the success of an organization (Long et al. ,1991; Goetsch \& Davis, 2014; Yahaya \& Ismail, 2004; Marron \& Cunniff, 2014; Parkay et al., 2014). However, based on our extensive reading on this area, it is evidence that less research has been conducted in exploring principals' competency in managing curriculum. Nonetheless, in any organization, managers are responsible for ensuring effective organizational operations and achieving the goals set (Baruah \& Ward, 2015; Miner, 2015). The success of a person managing the organization is depending on his or her 
knowledge and skill to implement management practices efficiently and effectively. Managerial skills are also a key determinant of productivity and organizational success (Drucker, 2013; Party, 2013). This statement is in line with Sin (2006) that principal is the one who will determine the success and failure of a school.

Focusing on effective curriculum management, through Educational Development (2001-2010), Ministry of Education has listed down a few strategies to be implemented in school. It includes practicing intellectual teaching and learning, providing guidelines to help principals play a role as a curriculum leaders, ensuring all prospective principals undergo the National Professional Qualification for Educational Leads (NPQEL) course, and strengthening the implementation of Quality Standards Malaysian Education (SKPM) at all schools.

Ibrahim (2007) said that criticisms associated with principals leadership and management has been hardly heard, but previous studies showed that dissatisfaction with the school management and administration is still being reported by many parties including the mass media. According to Ramlan (2002), there are times when criticisms are publicly said. Since the core business in school are teaching and learning (related to curriculum management), this study aims to further investigate this issue and find out what really happened in curriculum management in schools.

\section{Methodology}

The purpose of the study is to identify principals competency in curriculum management. The competency was determined by measuring principals' knowledge and skills. At the end of the study, recommendations have been made to improve principals competency in managing curriculum.

Specifically, the objectives of the study are to:

1. analyze principal knowlege in curriculum management based on principal self evaluation, senior assistant and senior teachers evaluation.

2. analyze principal skill in curriculum management based on principal self evaluation, senior assistant and senior teachers evaluation.

This survey study uses questionaires to collect data. The questionaires were administered to principals, senior assistants and senior teachers in every chosen school. A pilot study has completed prior to this study with the purpose of improving instruments reliability and validity. This study involves a number of schools which are geographically dispersed nationwide to ensure there are representatives of principals from all over Malaysia. The sampling method is based on school type categorized Ministry of Education (2014). Consequently, 2664 principals, senior assistants and senior teachers from each state in Malaysia were involved. The data has been analyzed descriptively using SPSS.

\section{Findings}

Based on the principals' self evaluation and evaluation of senior assistants and senior teachers, overall knowledge for curriculum management of the principals are at a high level (Table 1). In 
depth analysis shows that all respondents evaluate principals knowledge as at a high level, whether in determining steps to achieve curriculum goals successfully, in setting an achievable target, in determining an assessment method that suits various levels of students, or in implementing effective teaching and learning process with a mean score between 4.00 and 4.49. Principals also evaluate their knowledge in planning strategies to improve curriculum performance at a very high level (mean score 4.51), whereas senior assistants and senior teachers evaluation show that it is at a high level with mean scores 4.30 and 4.22, respectively. The lowest three for the knowledge are to determine the assessment method that suits the various levels of student intelligence, to implement effective teaching and learning processes and to determine the steps to achieve the goal of the curriculum successfully. Mean score between 4.00 to 4.19 .

Table 1: The Level of Curriculum Management Knowledge of the Principals

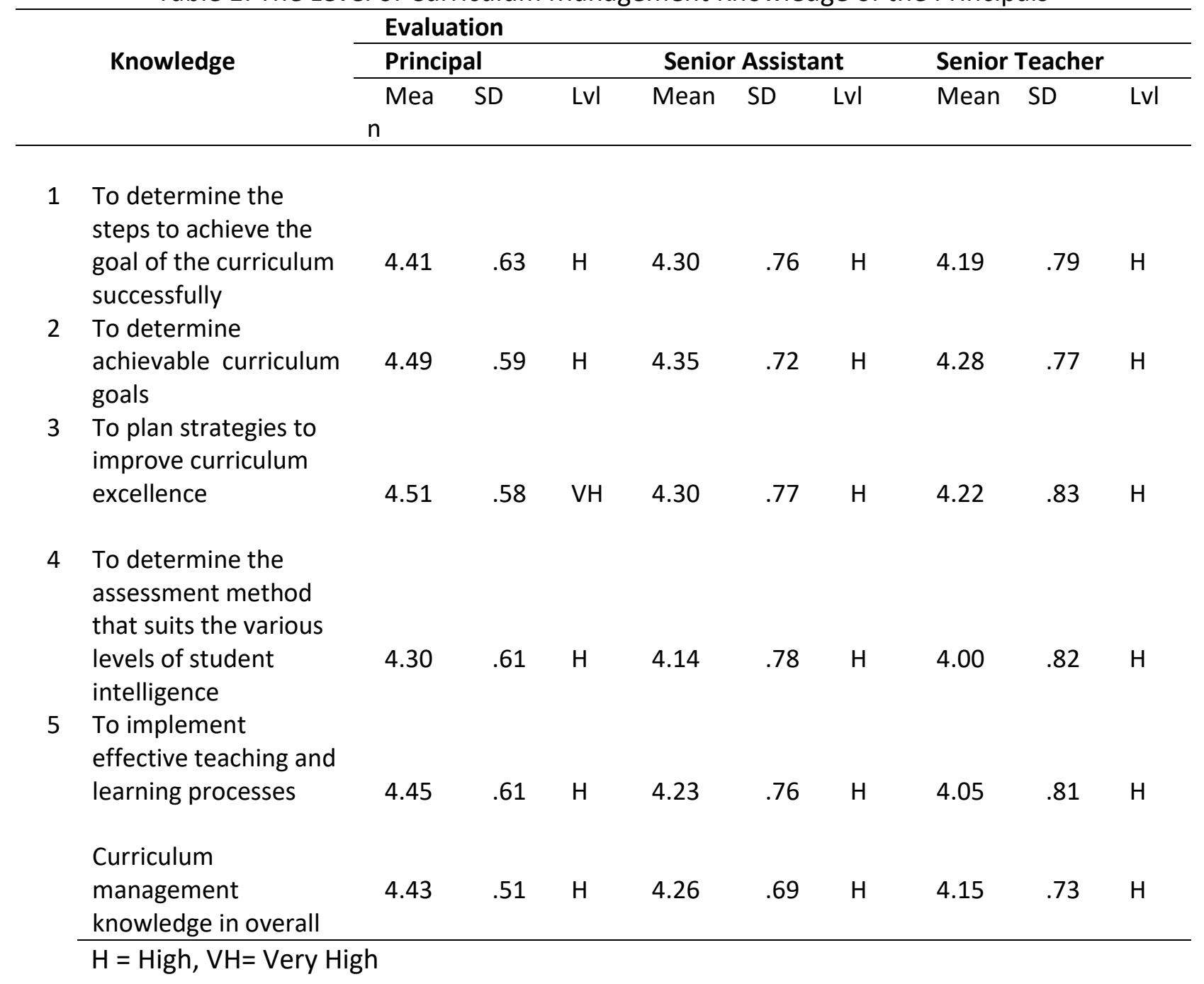

Table 2 shows that the three categories of respondents evaluate principals' skills in curriculum management as high with mean score 4.48 according to the principals' self-evaluation, 4.32 based 
on senior assistant evaluation, and 4.15 based on senior teacher evaluation. Detailed analysis shows that principals evaluate themselves as having very high skills in ensuring that curriculum change is fully implemented ( $m$ in score 4.53), in ensuring teaching and learning is being prioritized at all times (mean score 4.63), in promoting cooperation among all parties for smooth teaching and learning process (min score 4.55 ) and in implementing effective programme to increase curriculum achievement (mean score 4.52). However, assesment by senior assistants and senior teachers are at a lower level with means score between 4.19 and 4.44. The lowest three are the mean score for guiding teaching and learning process (3.98), overcoming problems of teaching and learning (4.05), and supervising teaching and learning as scheduled (4.11).

Table 2: The Level of Curriculum Management Skill of the Principals

\begin{tabular}{|c|c|c|c|c|c|c|c|c|c|c|}
\hline & \multirow{3}{*}{ Skill } & \multicolumn{9}{|c|}{ Evaluation } \\
\hline & & \multicolumn{2}{|c|}{ Principal } & \multirow[b]{2}{*}{ Lvl } & \multicolumn{3}{|c|}{ Senior Assistant } & \multicolumn{3}{|c|}{ Senior Teacher } \\
\hline & & Mean & SD & & Mean & SD & Lvl & Mean & SD & Lvl \\
\hline 1. & $\begin{array}{l}\text { Ensuring the } \\
\text { implementation of } \\
\text { curriculum change }\end{array}$ & 4.53 & .58 & VH & 4.36 & .74 & $\mathrm{H}$ & 4.24 & .80 & $\mathrm{H}$ \\
\hline 2. & $\begin{array}{l}\text { Ensuring teaching and } \\
\text { learning is being prioritized } \\
\text { at all times }\end{array}$ & 4.63 & .54 & VH & 4.44 & .73 & $\mathrm{H}$ & 4.31 & .83 & $\mathrm{H}$ \\
\hline 3. & $\begin{array}{l}\text { Supervising teaching and } \\
\text { learning as scheduled }\end{array}$ & 4.38 & .63 & $\mathrm{H}$ & 4.28 & .79 & $\mathrm{H}$ & 4.11 & .89 & $\mathrm{H}$ \\
\hline 4. & $\begin{array}{l}\text { Guiding teaching and } \\
\text { learning process }\end{array}$ & 4.42 & .60 & $\mathrm{H}$ & 4.20 & .81 & $\mathrm{H}$ & 3.98 & .92 & $\mathrm{H}$ \\
\hline 5. & $\begin{array}{l}\text { Promoting cooperation } \\
\text { among all parties for } \\
\text { smooth teaching and } \\
\text { learning process }\end{array}$ & 4.55 & .56 & VH & 4.35 & .74 & $\mathrm{H}$ & 4.20 & .86 & $\mathrm{H}$ \\
\hline 6. & $\begin{array}{l}\text { Overcoming problem of } \\
\text { teaching and learning }\end{array}$ & 4.33 & .58 & $\mathrm{H}$ & 4.21 & .77 & $\mathrm{H}$ & 4.05 & .83 & $\mathrm{H}$ \\
\hline 7. & $\begin{array}{l}\text { Implementing effective } \\
\text { programme to increase } \\
\text { curriculum achievement }\end{array}$ & 4.52 & .59 & VH & 4.37 & .76 & $\mathrm{H}$ & 4.19 & .86 & $\mathrm{H}$ \\
\hline & $\begin{array}{l}\text { Curriculum management } \\
\text { skill in overall }\end{array}$ & 4.48 & .46 & $\mathrm{H}$ & 4.32 & .67 & $\mathrm{H}$ & 4.15 & .77 & $\mathrm{H}$ \\
\hline
\end{tabular}

\section{Discussions}

The data shows that the principals in Malaysia show very high competencies in only certain areas, and high level management skills on the others. The senior assistants and senior teachers have high 
level of management skills in all areas. Based on the findings, this study recommends that from time to time, principals attend training course to improve their compency. This is due to the facts that principals' knowledge to determine the assessment method that suits the various levels of student intelligence, to implement effective teaching and learning processes, and to determine the steps to achieve the goal of the curriculum successfully still at a lower level. Principals' skill to supervise teaching and learning as scheduled, to guide teaching and learning process, to overcome problem of teaching and learning, and to implement effective programme to increase curriculum achievement should also be improved. Besides, principals should been trained for:

i. managing time wisely. This is to ensure that principals can implement teaching and learning as well as monitoring without relying heavily on subordinates. Effective time management enable principals to regularly participate in school activities.

ii. having capability to build close relationships with teachers. Activities that provide two-way communication between principals and teachers need to be increased. Principals should practice open door policy and welcome subordinates to discuss curriculum matters openly. Frequent communication will create opportunities for principals and teachers understand each other better.

iii. building close relationships with students. It can be achieved by doing things together. Programs such as talks, Yasin ceremonies and so on should be organised regularly.. Close ties can also be created through unofficial programs such as praying, playing and eating together. This practice can minimize disciplinary problems.

iv. welcoming parents and outsiders that can contribute their expertise to the school. Good relationship or networking with outsiders need to be improved either officially or unofficially. This practices can increase all kind of contribution to schools.

v. improving capacity building skills in order to avoid negative perceptions towards his task accountability. Capacity must be followed by reporting so that the principal's responsibility for the particular tasks are noticeable.

\section{Conclusion}

This study has sucessfully explained principals' compentency in curriculum management which was determined by measuring principals' knowledge and skill. However principals should aim for continuous profesional development and practice life long learning in order to improve their competency. Future study should investigate the profesional development of principals from various aspects to ensure quality education being delivered to the students.

\section{Corresponding Author}

Zaida Nor Zainudin, PhD

Email: zaidanor@upm.edu.my

Faculty of Educational Studies,

Universiti Putra Malaysia,

43400 Serdang, Selangor,

Malaysia 
INTERNATIONAL JOURNAL OF ACADEMIC RESEARCH IN BUSINESS AND SOCIAL SCIENCES

Vol. 8, No. 10, Oct. 2018, E-ISSN: 2222-6990 ㄷ 2018 HRMARS

\section{References}

Abd. Razak, N., \& Abdullah, W. M. R. (2003). Practice of principals from teacher perspective. Digest Educator 3 (1): 23-35.

Baruah, B., \& Ward, A. (2015). Metamorphosis of intrapreneurship as an effective organizational strategy. International Entrepreneurship And Management Journal, 11(4), 811-822.

Drucker, P. (2013). Managing for the Future. New York: Routledge.

Goetsch, D. L., \& Davis, S. B. (2014). Quality management for organizational excellence. Upper Saddle River, NJ: Pearson.

Ibrahim, M. S. (2007). System of mentoring among principals. The 14th National Seminar on Management and Leadership of Education. Pahang: Institut Aminuddin Baki. 26-27 June.

Long, A., Rejab, I., Sultan, A.A., Long, M.N., Nordin, M.S., Ismail, N. A. H., Ashraf, R., \& Hashim, R. (1991). Factors that contribute to the improvement of schools' progress: Case studies. Proceeding in Seminar Teaching Between University. Kuala Lumpur: International Islamic University of Malaysia.

Marron, J. M., \& Cunniff, D. (2014). What is an innovative educational leader? Contemporary Issues in Education Research (Online), 7(2), 145.

Miner, J. B. (2015). Organizational behavior 1: Essential theories of motivation and leadership. Routledge.

Ministry of Education. (2014). Malaysia educational statistics. Putrajaya: Educational Planning and Research Division, Ministry of Education.

Parkay, F. W., Anctil, E. J., \& Hass, G. (2014). Curriculum leadership: Readings for developing quality educational programs. USA: Prentice Hall.

Party, L. (2013). An enterprising nation: The final report of the small business taskforce. London.

Sin, I. (2006). Construction Instrument Review. Sintok, Kedah: Universiti Utara Malaysia. Memo, 3 Jun.

Ramlan, A. (2002). A study on the causes and stress factors of the field among secondary school administrators in Klang Selangor. Unpublished thesis. Universiti Kebangsaan Malaysia.

Yahaya, N., \& Ismail, S. (2004). Principal leadership behavior and its relationship with work pressure and organizational effectiveness in selected schools in Negeri Sembilan. Proceedings of the 12th National Education Management and Leadership Seminar 2004, p. 183-195. 